\title{
Environmental tobacco smoke awareness and exposure: impact of a statewide clean indoor air law and the report of the US Environmental Protection Agency
}

\author{
Ross C Brownson, James R Davis, Jeannette Jackson-Thompson, Joan C Wilkerson
}

\begin{abstract}
Objective-To determine whether a statewide clean indoor air law and the report of the US Environmental Protection Agency (EPA) affected awareness of and exposure to environmental tobacco smoke.

Design-Cross sectional telephone survey.

Setting-Missouri, United States, 19901993.

Participants - Population based sample of Missouri residents aged $\geqslant 18$ years $(n$ =6052).
\end{abstract}

Main outcome measures-A special series of questions was added to ascertain environmental tobacco smoke awareness, workplace and home exposure, and actions to reduce restaurant exposure.

Results - Awareness of the state law increased following enactment $(p<0.001)$. Workplace exposure varied between the pre- and the post-state law periods $(44.2 \% v 34.7 \% ; p<0.001)$. A slight decline in workplace environmental tobacco smoke exposure before the state law was enacted accelerated after it was enacted. The report of the EPA did not appear to increase this trend. Self reported home exposure to environmental tobacco smoke did not vary significantly over the study period. The percentage of nonsmokers asking to be seated in the nonsmoking section of a restaurant increased in the post-state law period.

Conclusions - A statewide clean indoor air law is beneficial in reducing nonsmokers' exposure to environmental tobacco smoke. Despite improvements, non-smoker exposure to environmental tobacco smoke remains widespread, and more comprehensive measures are necessary.

(Tobacco Control 1995; 4: 132-138)

Keywords: exposure; public policy; survey; tobacco smoke pollution

Correspondence and reprin requests to Dr RC

Brownson, Dr RC Community Health, School of Public Health, Saint of Public Health, Saint Lindell Boulevard, St Louis, MO 63108-3342, USA

\section{Introduction}

The detrimental health effects of exposure to environmental tobacco smoke are now well established. ${ }^{1-4}$ Environmental tobacco smoke is known to cause lung cancer in non-smokers and lower respiratory tract infections in infants and children, ${ }^{1-4}$ and has been linked with heart disease $^{5}$ and sudden infant death syndrome. ${ }^{6}$

In "Healthy people 2000: National health promotion and disease prevention objectives"? - the nation's public health goals - it was proposed that comprehensive clean indoor air laws strictly limiting smoking in public places and worksites should be enacted in all 50 states. A "comprehensive" law was defined as one including private and public workplaces. ${ }^{7}$ As of August 1994, 41 states had enacted laws restricting smoking in at least one public place, and 16 states had enacted comprehensive laws affecting workplaces. ${ }^{8}$ In addition, hundreds of local jurisdictions have enacted regulations to limit public smoking. ${ }^{8-11}$

Despite the widespread implementation of public smoking restrictions, few data exist on the effectiveness of these restrictions in reducing environmental tobacco smoke exposure among non-smokers. A recent study from California suggested that strong local smoking ordinances reduce non-smokers' workplace exposure to tobacco smoke. ${ }^{12}$ However, no study to date has examined whether statewide smoking restrictions affect environmental tobacco smoke exposure on a population basis. Evaluation of the effects of public smoking restrictions has been cited as an important public health objective..$^{10,13,14}$

There were no statewide restrictions on public smoking in Missouri until 1992. However, during the 1992 Missouri General Session, statewide clean indoor air legislation was enacted that restricted smoking in workplaces, public buildings, and restaurants. ${ }^{15}$

In addition to tobacco control advances at the state level, the report of the US Environmental Protection Agency (EPA) was released in January 1993.4, ${ }^{46}$ The EPA report designated environmental tobacco smoke as a group A (known human) carcinogen. ${ }^{4}$ By placing environmental tobacco smoke in the same category with a small group of known carcinogens (for example, asbestos, benzene, radon), it became subject to similar regulatory 


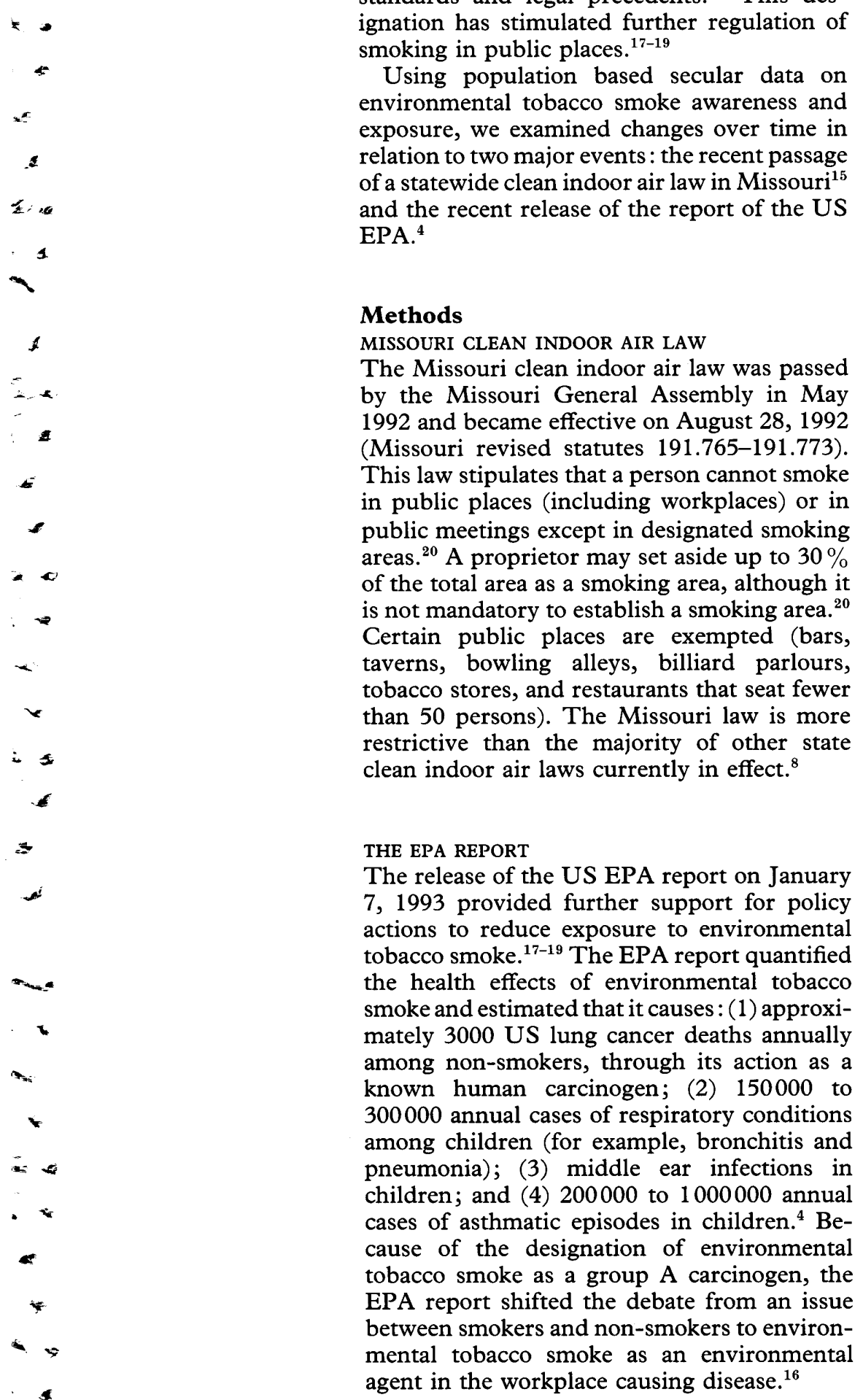

6 standards and legal precedents. ${ }^{16}$ This designation has stimulated further regulation of moking in public places. ${ }^{17-19}$

sing population based secular data on exposure, we examined changes over time in posure, we examined change the recent passage and the recent release of the report of the US EPA. ${ }^{4}$

\section{Methods}

The Missouri clean indoor air law was passed by the Missouri General Assembly in May 1992 and became effective on August 28, 1992 (Missouri revised statutes 191.765-191.773). This law stipulates that a person cannot smoke in public places (including workplaces) or in public meetings except in designated smoking A proprietor may set aside up to $30 \%$ is not mandatory to establish a smoking area ${ }^{20}$ Certain public places are exempted (bars, taverns, bowling alleys, billiard parlours, that seat fewer restrictive than the majority of other state clean indoor air laws currently in effect. ${ }^{8}$

\section{THE EPA REPOR}

The release of the US EPA report on January 7, 1993 provided further support for policy actions to reduce exposure to environmental the health effects of environmental tobacco smoke and estimated that it causes: (1) approximately 3000 US lung cancer deaths annually mong non-smokers, through its action as a 300000 annual cases of respiratory conditions among children (for example, bronchitis and pneumonia); (3) middle ear infections in children; and (4) 200000 to 1000000 annual cause of the designation of environmental tobacco smoke as a group A carcinogen, the EPA report shifted the debate from an issue mental tobacco smoke as an environmental agent in the workplace causing disease. ${ }^{16}$

ENVIRONMENTAL TOBACCO SMOKE SURVEY DATA Population based exposure to environmental tobacco smoke was ascertained through the behavioural risk factor surveillance system (BRFSS), which was developed in 1981 by the US Centers for Disease Control and Prevention (CDC). The BRFSS provides a flexible, state health agency based surveillance system to assist in planning, implementing, and evaluating health promotion and disease prevention programmes. ${ }^{21,22}$

We shall briefly review survey methods, which have been discussed in detail elsewhere. ${ }^{21-23}$ Using random digit dialling, ${ }^{24}$ a random sample was selected from Missouri's non-institutionalised adult population (aged $\geqslant 18$ years) who had telephones. The survey was administered by trained interviewers during a two week period, beginning on the second Wednesday of each month, between January 1990 and December 1993. During each month, approximately 126 interviews were conducted - a total of 6052 interviews over the entire study period. Among eligible respondents (that is, working phones, nonbusiness phone extensions), the response rate was $73 \%$. Our sample was generally representative of the overall Missouri population, ${ }^{25}$ although it slightly underrepresented younger persons, males, blacks, and persons with less education (table 1).

The BRFSS instrument consisted of standardised questions developed by CDC, plus state-added questions on various topics. In 1990, and again in 1991 and 1992, the Missouri Department of Health added a series of questions (based mainly on earlier surveys $^{27-31}$ ) to ascertain beliefs about environmental tobacco smoke, exposure to tobacco smoke, and actions taken to reduce exposure.

\section{STATISTICAL ANALYSES}

Following completion of each month's interviewing cycle, BRFSS data were edited and weighted to adjust for the probability of selection, and for the age, race, and gender distribution of the population. ${ }^{25,32,33}$ Our previous work $\mathrm{k}^{30}$ has shown that sociodemographic variables may affect behaviours to reduce exposure to environmental tobacco smoke.

To assess changes over time, we primarily analysed four special questions (table 2 ). These questions measured awareness of the state clean indoor air law, self reported tobacco smoke exposure at work and in the home, and action to reduce environmental tobacco smoke exposure in restaurants by asking for nonsmoking seating. For analyses of workplace tobacco smoke exposure, respondents who were unemployed or retired were excluded. Although the state clean indoor air law was not anticipated to affect home tobacco smoke exposure, this variable was analysed for comparison with variables more directly affected by new ordinances and regulations (for example, workplace exposure).

We limited our analyses to never-smokers and former smokers, who were defined as "non-smokers" for the study. Smoking status was ascertained through standard questions: "Have you smoked at least 100 cigarettes in your lifetime?" and "Do you smoke cigarettes now?"

For each of the questions of interest, we calculated weighted, two month averages and weighted prevalence measures for time periods of interest before and after the state law and release of the EPA report. We used the gaussian $\mathrm{z}$ statistic to compare prevalence rates between time periods. ${ }^{33}$

For regression analyses, a line of best fit using the least squares techniques was constructed for variables on exposure and actions based on the two month averages. For each 
Table 1 Respondent characteristics by sociodemographic grouping, Missouri, 1990-1993

\begin{tabular}{|c|c|c|c|}
\hline Characteristic & Number & Sample \% & $\begin{array}{c}\text { Census } \%{ }^{a} \\
\text { (Missouri/US) }\end{array}$ \\
\hline \multicolumn{4}{|l|}{ Age (years) } \\
\hline $\begin{array}{l}18-34 \\
35-54\end{array}$ & 1921 & 31.8 & $35.9 / 37.7$ \\
\hline $55+$ & 2027 & 33.5 & $33.1 / 34.1$ \\
\hline Unknown/refused & 2069 & 34.2 & $30.9 / 28.3$ \\
\hline Gender & 35 & 0.5 & \\
\hline Female & 3605 & 59.6 & $52.9 / 52.2$ \\
\hline Male & 2447 & 40.4 & $47.1 / 47.8$ \\
\hline \multicolumn{4}{|l|}{ Race } \\
\hline White & 5435 & 89.8 & $88.8 / 82.2$ \\
\hline African American & 501 & 8.3 & $9.7 / 11.0$ \\
\hline Other & 116 & 1.9 & $1.5 / 6.8$ \\
\hline \multicolumn{4}{|l|}{ Education level } \\
\hline Less than high school graduate & 1097 & 18.1 & $25.5 / 24.6$ \\
\hline High school or technical school graduate & 3694 & 61.0 & $58.1 / 50.9$ \\
\hline College graduate & 1253 & 20.7 & $16.4 / 24.6$ \\
\hline Unknown/refused & 8 & 0.1 & \\
\hline \multicolumn{4}{|l|}{ Smoking status } \\
\hline Never smoked & 3039 & 50.2 & $50.2^{\mathrm{b}}$ \\
\hline Former smoker & 1451 & 24.0 & 24.1 \\
\hline Current smoker & 1547 & 25.6 & 25.7 \\
\hline Unknown/refused & 15 & 0.2 & \\
\hline
\end{tabular}

Based on the 1990 US Census population aged 18 years and older. ${ }^{25}$

b US smoking rates for 1991 . $^{6}$

Table 2 Questions used to measure awareness, exposure, and actions to reduce environmental tobacco smoke (ETS) exposure, and beliefs about ETS, Missouri, 1990-1993

\begin{tabular}{ll} 
Category & Question \\
\hline Awareness of state law & $\begin{array}{l}\text { Is there a state law in Missouri that limits smoking in public places such as grocery } \\
\text { stores, restaurants, and shopping malls? } \\
\text { When you are at work, are you exposed to the smoke from other people's cigarettes, } \\
\text { pipes, or cigars? } \\
\text { When you are at home, are you exposed to the smoke from other people's cigarettes, } \\
\text { pipes, or cigars? } \\
\text { In the past year, have you asked to be seated in the nonsmoking area of a restaurant? }\end{array}$ \\
\hline
\end{tabular}

Table 3 Comparison of environmental tobacco smoke (ETS) awareness, exposure, and action during three time periods, Missouri, 1990-1993

\begin{tabular}{|c|c|c|c|c|c|c|}
\hline \multirow[b]{2}{*}{ Variable } & \multicolumn{3}{|c|}{ Percentage $( \pm 95 \%$ confidence interval) } & \multicolumn{3}{|c|}{$p$ Value for difference ${ }^{\mathrm{a}}$} \\
\hline & Period $(1)^{\mathrm{b}}$ & $\operatorname{Period}(2)^{\mathrm{c}}$ & Period (3) ${ }^{\mathrm{d}}$ & $(1)(2)$ & (1) (3) & (2) (3) \\
\hline $\begin{array}{l}\text { Aware of state law } \\
\text { restricting ETS }\end{array}$ & $42.6 \pm 3.7$ & $56.3 \pm 5.4$ & $48.9 \pm 3.2$ & $<0.001$ & 0.013 & 0.021 \\
\hline $\begin{array}{l}\text { Exposed-workplace } \\
\text { Exposed-home } \\
\text { Asked for non-smoking }\end{array}$ & $\begin{array}{l}44.2 \pm 2.6 \\
18.5 \pm 1.6 \\
76.4 \pm 2.2\end{array}$ & $\begin{array}{l}33.2 \pm 6.3 \\
14.3 \pm 3.8 \\
84.2 \pm 3.7\end{array}$ & $\begin{array}{l}34.7 \pm 4.1 \\
16.8 \pm 2.4 \\
82.2 \pm 2.5\end{array}$ & $\begin{array}{r}0.01 \\
0.05 \\
<0.001\end{array}$ & $\begin{array}{c}<0.001 \\
>0.10 \\
0.001\end{array}$ & $\begin{array}{l}>0.10 \\
>0.10 \\
>0.10\end{array}$ \\
\hline
\end{tabular}

a Two tailed.

b Awareness of law restricting ETS: January 1992-August 1992; exposed in workplace or home: January 1990-August 1992; asked for non-smoking area in restaurant: January 1991-August 1992.

c For all variables: September 1992-December 1992.

d For all variables: January 1993-December 1993.

linear model, $\mathbf{R}^{2}$ values, slope estimates, and standard errors of slopes were calculated. We used Student's $t$ test $^{34}$ to determine whether the slope was significantly different from zero.

To assess the possible confounding effects of local (that is, city or county) ordinances on environmental tobacco smoke exposure, we reran all analyses excluding counties for which $\geqslant 50 \%$ of the population was covered by a comprehensive smoking control ordinance (that is, restricting smoking in workplaces, restaurants, and other public places) before the beginning of the study. ${ }^{11}$ In Missouri, only four communities had smoking control ordinances that included workplace restrictions over the entire study period.11 These analyses had minimal impact on the results based on the full dataset; therefore, only results based on the complete dataset are presented.

\section{Results}

Table 3 presents awareness, exposure to environmental tobacco smoke, and action to reduce restaurant tobacco smoke exposure for three periods of interest: (1) before the state law; (2) after the state law but before EPA; and (3) after EPA. Awareness of the state law increased following the effective date of the law $(p<0.001)$. During the post-EPA period (January 1993 to December 1993), awareness of the state law was $48.9 \%$. Awareness of the state law was significantly higher in period 2 than in period 3. Although not shown in the table, the "don't know" response was common during the post-state law period $(32.1 \%$ of respondents).

Self reported exposure to environmental tobacco smoke in the workplace decreased substantially between period 1 and subsequent periods (table 3). Over the entire study period, 
Percent Exposed

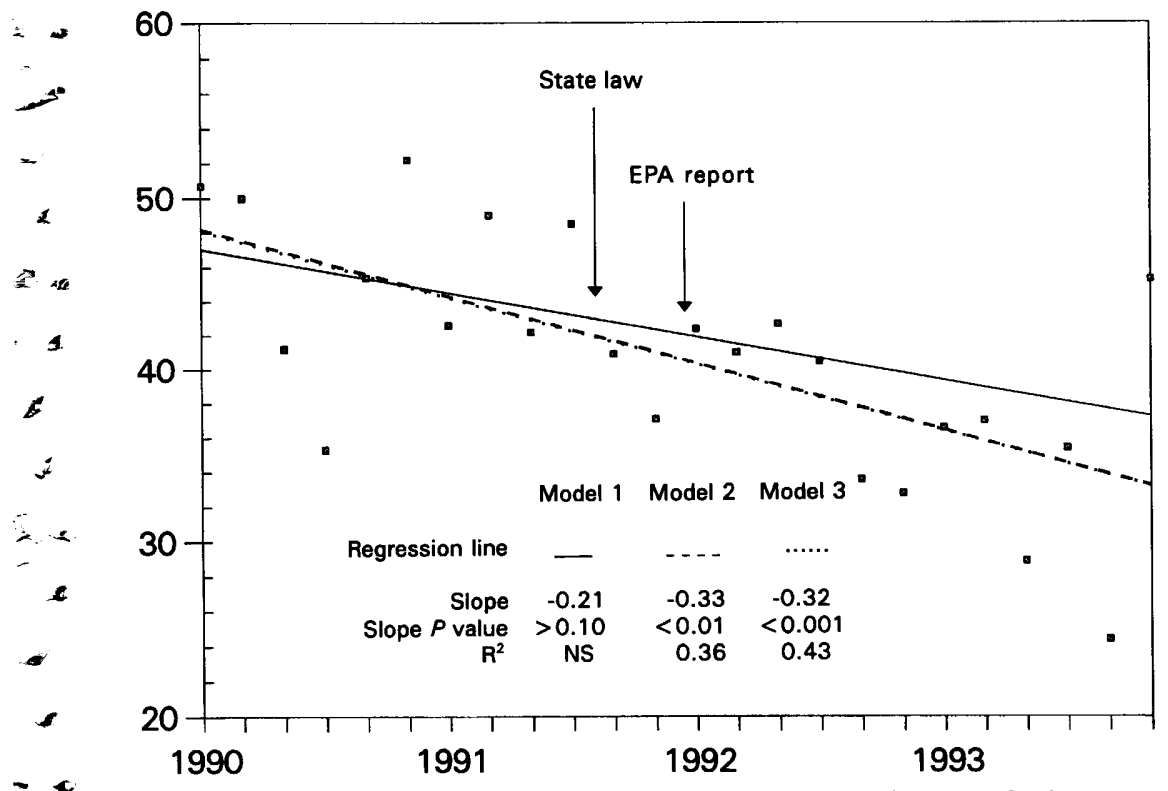

- Figure 1 Weighted prevalence of self-reported exposure to environmental tobacco smoke in the workplace, Missouri, 1990-1993. Model 1 = fanuary 1990-August 1992; model 2 = Fanuary 1990-December 1992; model 3 = fanuary 1990-December 1993. EPA, Environmental Protection Agency.

i.

2

$=$

5

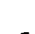

.

$+$

$\checkmark$

$-2$

- *

$-$

$\rightarrow$

\section{Percent Exposed}

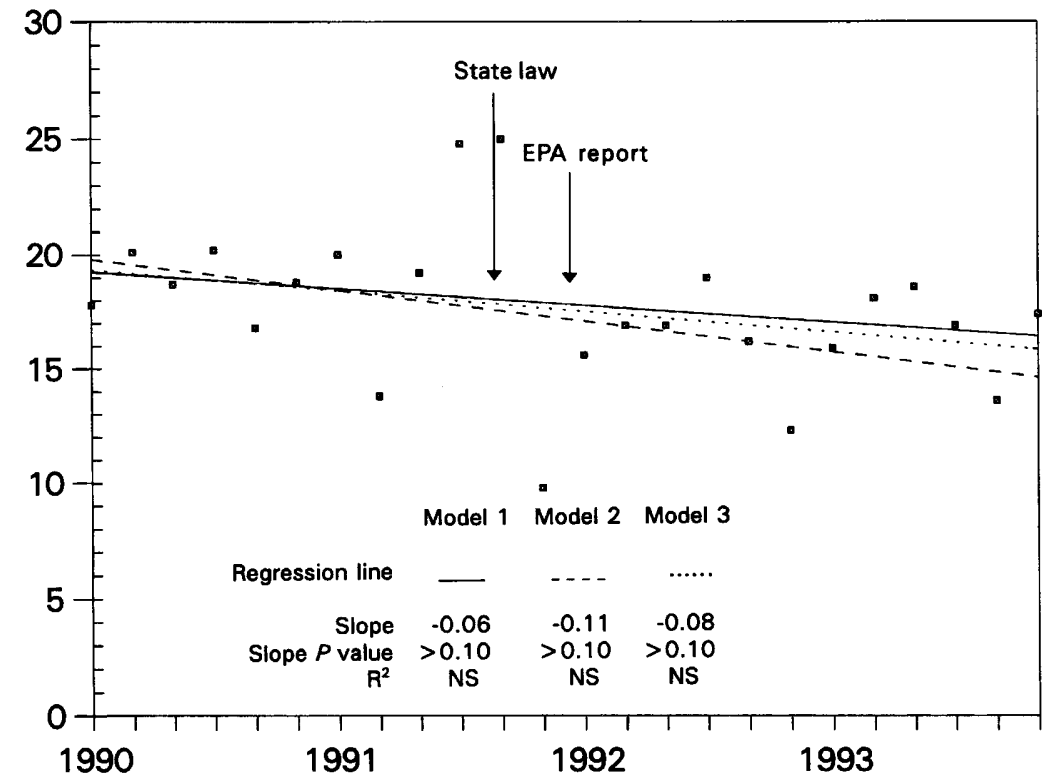

Figure 2 Weighted prevalence of self reported exposure to environmental tobacco smoke in the home, Missouri, 1990-1993. Model 1 = fanuary 1990-August 1992; model 2 = Fanuary 1990-December 1992; model 3 = Fanuary 1990-December 1993. EPA, Environmental Protection Agency.

non-smokers' exposure in the workplace was $40.7 \% \quad(95 \%$ confidence interval $(\mathrm{CI})=$ 38.6-42.9). Exposure varied 10 percentage points between periods 1 and $3(44.2 \% v$ $34.7 \% ; \mathrm{p}<0.001)$. Exposure to environmental tobacco smoke in the home for the entire study period was $17.8 \% \quad(95 \% \quad \mathrm{CI}=$ 16.5-19.0). Self reported home exposure did not vary between periods 1 and $3(\mathrm{p}>0.10)$. Over the entire study period, $79.2 \%$ (95\% CI $=77.7-80.8$ ) of non-smokers had asked to be seated in the non-smoking section of a restaurant within the past year. The percentage asking for a non-smoking section ranged from
$76.4 \%$ in period 1 to $82.2 \%$ in period 3 ( $\mathrm{p}<$ $0.001)$. None of the factors on exposure or non-smoking preference in restaurants varied significantly between periods 2 and 3 .

A non-significant decline in workplace exposure to environmental tobacco smoke was occurring before enactment of the state clean indoor air law (model 1 in figure 1). When the model included the period August 1992 to December 1992 (model 2) or the period August 1992 to December 1993 (model 3), the slope values were larger and identical. Therefore, the regression lines for models 2 and 3 overlap. The $R^{2}$ value was largest for model $3\left(R^{2}=\right.$ 0.43 ), suggesting the best linear fit for this model. The $\mathrm{R}^{2}$ value is not shown for model 1 because the slope estimate was not significantly different from 0 .

Among the three regression models predicting home environmental tobacco smoke exposure, the slope estimate was largest for model $2(\beta=-0.11$ ) (figure 2$)$. None of the three models resulted in a statistically significant slope estimate, suggesting that home environmental tobacco smoke exposure did not decline significantly over the study period. No $R^{2}$ values are presented because of the nonsignificant slope estimates.

Increasing preference for restaurant nonsmoking areas was identified in models 2 and 3 , with a larger slope in model $2(\beta=0.38)$ (figure 3 ). The $\mathrm{R}^{2}$ value was largest for model $3\left(\mathbf{R}^{2}=0.38\right)$.

\section{Discussion}

These population based survey data are among the first published evidence of the effects of a statewide clean indoor air law and the report of the US EPA on environmental tobacco smoke awareness, exposure, and action to reduce exposure in restaurants.

We documented increasing awareness of smoking restrictions, ranging from $42.6 \%$ before enactment of the law to $56.3 \%$ in the four month period after the law became effective. However, in the most recent time period (period 3), more than half of nonsmoking respondents were unaware of the state clean indoor air law, indicating the need for substantial public education efforts. Intense media coverage e $^{35-39}$ and public education efforts ${ }^{20}$ around the effective date of the state law may have increased awareness for a period of several months. While one might expect awareness to increase around the time of passage of the law (May 1992), media coverage around the effective date appears to have had a larger effect on public awareness.

Exposure to tobacco smoke in the workplace was significantly reduced in the period following enactment of the state clean indoor air law. However, even in the most recent time period (period 3), over one third of respondents reported exposure to tobacco smoke in the workplace. Earlier data from California suggest that adequate protection of non-smokers from tobacco smoke requires a total ban on workplace smoking, ${ }^{40}$ such as those recently enacted in California through 
Percent

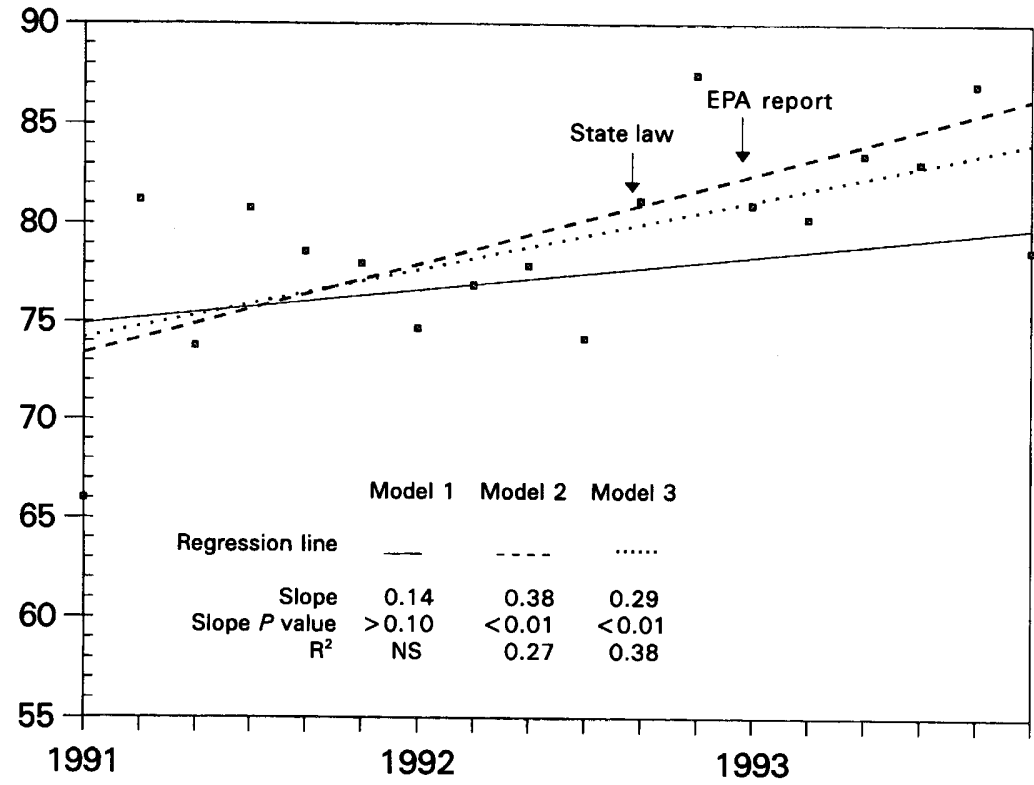

Figure 3 Weighted prevalence of asking to be seated in a non-smoking area of a restaurant, Missouri, 1991-1993. Model 1 = fanuary 1991-August 1992; model $2=$ fanuary 1991-December 1992; model $3=$ fanuary 1991-December 1993. EPA, Environmental Protection Agency. particularly for children. ${ }^{45,46}$ Additional efforts to educate the public about the health effects of environmental tobacco smoke, such as the current campaign from the US Centers for Disease Control and Prevention (ie, "Secondhand Smoke: We're All At Risk"), ${ }^{47}$ are warranted.

The primary goal of the Healthy people 2000 objective calling for comprehensive state smoking laws is to protect non-smokers from the health hazards of environmental tobacco smoke exposure. ${ }^{7}$ An additional benefit from clean indoor air regulations may be a reduction in smoking prevalence among workers and the general public. For example, in a recent multivariate analysis, Emont $e t a l^{48}$ found that moderate or extensive clean indoor air laws were associated with a lower smoking rate and a higher proportion of quitters. Rigotti and Pashos $^{9}$ found an association between local smoking restrictions and smoking prevalence. Because our study involved statewide restrictions and we lack a comparison group, we are unable to examine the possible effect of the statewide law on smoking prevalence.

The limitations of our study should be noted. We relied on self reported telephone survey data and had no comprehensive information on the reliability and validity of the BRFSS data during the entire study period. However, previous studies ${ }^{31,49,50}$ have shown relatively high accuracy of BRFSS-collected data on reported cardiovascular risk factors and on demographics. In addition, a 1993 testretest study of the Missouri BRFSS found relatively high reliability for questions involving individual actions to reduce exposure to environmental tobacco smoke ( $\kappa$ values 0.62 to 0.82$).{ }^{31}$ Since BRFSS relies on telephone interviews, potential exists for response bias because of lack of phone coverage among certain sociodemographic groups. ${ }^{51}$

Because of the limited number of questions available for analysis and the self reported nature of the information, we were unable to differentiate some important measurement issues. For example, we cannot quantify the frequency of exposure to high levels of environmental tobacco smoke, which may be important in determining lung cancer risk in non-smokers. ${ }^{52}$ In addition, comparisons of ambient and biological measurements with self reported data have suggested discrepancies. ${ }^{53,54}$

There also may be other intervening variables that may account for some of the changes in environmental tobacco smoke exposure observed over time. For example, Missouri is one of 17 states participating in the American Stop Smoking Intervention Study (Project ASSIST). ${ }^{10,55}$ The Missouri ASSIST program has selected environmental tobacco smoke exposure as one of its priorities. ${ }^{56}$ However, because full scale interventions did not begin until fall 1993, it is unlikely that Missouri ASSIST affected our findings. It is also possible that more time is needed to evaluate the effects of the EPA report, since further action based on the report (for example, regulation of environmental tobacco smoke by non-smoka significant decline the home. Because the Missouri law does not affect private residences, we did not anticipate a decline in home tobacco smoke exposure over the study period. However, tobacco smoke exposure in the home is a health hazard, ${ }^{4}$ legislation ${ }^{41}$ and in Maryland through state regulation. ${ }^{42}$ Action to reduce exposure in non-smoking section, also increased significantly following the policy initiatives.

pare our findings. Point-in-time survey data strong local tobacco control ordinances. Pierce affirmative response to: "During the past two you work?" Using this question area in which environmental tobacco smoke exposure at on the presence of local smoking control ordinances. Our study found that workplace $34.7 \%$ in period 3 . The variations between Missouri and California data are not California Proposition 99, with its aggressive antismoking media campaign ${ }^{43,44}$ Also, loca Calfornia (190 local smoking ordinance restrictions). ${ }^{11,12}$ This compares with seven including four with workplace restrictions. ${ }^{11}$ The presence of local ordinances in Missour impact on overall exposure to environmental tobacco smoke, because exclusion of localities ith comprehensive ordinances did not affect

Our data showed no significant decline
Our das. 
the Occupational Safety and Health Administration) may take several years to implement.

In summary, our findings indicate that a statewide clean indoor air law is beneficial in reducing non-smokers' exposure to environmental tobacco smoke in the workplace. Over the study period, the report of the US EPA does not appear to have accelerated significantly the rate of decline in non-smokers' exposure to environmental tobacco smoke in the workplace. Our study, coupled with earlier work from California, ${ }^{12,57}$ indicates that comprehensive state clean indoor air laws and regulations should be used in combination with local ordinances to control environmental tobacco smoke exposure on a population basis. In addition, this study and earlier studies ${ }^{30,58}$ show the usefulness and flexibility of the BRFSS, the world's largest health surveillance system, for evaluation of policy related disease prevention initiatives.

The authors are grateful to supervisors and surveyors from Manpower, Inc, who conducted data collection. We also thank Dr Theophili Murayi, Division of Chronic Disease Prevention and Health Promotion, Missouri Department of Health, and Dr Michael Siegel of the Office on Smoking and Health, Centers for Disease Control and Prevention, for helpful suggestions on the manuscript. This study was supported in part by Centers fo

1 US Department of Health and Human Services. The health consequences of involuntary smoking. A report of the consequences of involuntary smoking. A report of the Health Service, Centers for Disease Control, 1986. (DHHS Publication No (CDC) 87-8398.)

2 National Research Council. Board on Environmental Studies and Toxicology. Committee on passive smoking environmental tobacco smoke. Measuring exposures and assessing health effects. Washington, DC: National Academy Press, 1986.

3 US Department of Health and Human Services. Environmental tobacco smoke in the workplace: lung cancer and other health effects. Cincinnati, Ohio: National Institute for Occupational Safety and Health, 1991. (DHHS for Occupational Safety and Healt

4 US Environmental Protection Agency Respiratory health effects of passive smoking : lung cancer and other disorders. effects of passive smoking : lung cancer and other disorders. Washington, DC: Office of Health and Environmental
Assessment, 1992. (Publication No EPA/600/6-90/ 006F.)

5 Glantz SA, Parmley WW. Passive smoking and heart disease: epidemiology, physiology, and biochemistry. Circulation 1991; 83: 1-12.

6 Schoendorf KC, Kiely JL. Relationship of sudden infant death syndrome to maternal smoking during and after pregnancy. Pediatrics 1992; 90: 905-8.

7 US Department of Health and Human Services. Healthy people 2000: national health promotion and disease prevention objectives. Washington, DC: US Government Printtion objectives. Washington, DC: US Government Print-

8 Brownson RC, Matson DM, Novotny TE, Hughes RG, Eriksen MP. Environmental and policy interventions to control tobacco use and prevent cardiovascular disease.

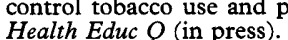

9 Rigotti NA, Pashos CL. No-smoking laws in the United States. An analysis of state and city actions to limit smoking in public places and workplaces. $\mathcal{F} A M A 1991$ 266: 3162-7.

10 US Department of Health and Human Services. Strategies to control tobacco use in the United States: a blueprint for public health action in the 1990 s. Bethesda, Maryland: US Public Health Service, National Institutes of Health, National Cancer Institute, 1991. (NIH Publication No 92-3316.)

11 Pertschuk M, Shopland DR, eds. Major local smoking ordinances in the United States. Smoking and tobacco ordinances in the United States. Smoking and tobacco Institutes of Health, Public Health Service, US Dept of Institutes of Health, Public Health Service, US Dept of Health and Human Services, Nation

12 Pierce JP, Shanks TG, Pertschuk M, Gilpin E, Shopland $\mathrm{D}$, Johnson $\mathrm{M}$, et al. Do smoking ordinances protect nonsmokers from environmental tobacco smoke? Tobacco Control 1994; 3: 15-20.

13 Burns DM, Axelrad R, Bal D, Carol J, Davis RM, Myers ML, et al. Report of the tobacco policy research study group on smoke-free indoor air policies. Tobacco Control 1992; 1(suppl): S14-18.
14 Novotny TE. Tobacco use. In: Brownson RC, Remington PW, Davis JR, eds. Chronic disease epidemiology and control. Washington, DC: American Public Health Association, 1993.

15 Davis JR, Brownson RC. A policy for clean indoor air in Missouri: history and lessons learned. Saint Louis University Public Law Review 1994; 13: 749-62.

16 Burns DM. The EPA report: why the tobacco contro world will never be the same. Tobacco Control 1993; 2 3-4.

17 Conlisk EA, Siegel M, Lengerich E, Malek S, Eriksen M. The impact of a smoker's rights bill on local smoking regulations in North Carolina. Presented at the 43rd Annual Epidemic Intelligence Service Conference, Apri 19-22, 1994, Atlanta, Georgia.

18 Manning A. Smoke report may change public habits. US $A$ Today; January 7, 1993.

19 Smoke study prompts new limits. Study of secondhand effects spurs states and businesses to act. St Louis PostDispatch; March 1, 1993.

20 Missouri Coalition on Smoking and Health. What you should know about Missouri's clean indoor air law. Columbia, MO: Missouri Coalition on Smoking and Health, 1992 .

21 Gentry EM, Kalsbeek WD, Hogelin GC, et al. The behavioral risk factor surveys: design, methods, an estimates from combined state data. Am $\mathcal{F}$ Prev $M e d$ $1985 ; 1: 9-14$

22 Remington PL, Smith MY, Williamson DF, Anda RF Gentry EM, Hogelin GC. Design, characteristics, and usefulness of state-based behavioral risk factor surveil-
lance: 1981-1987. Public Health Rep 1988; 103: 366-75.

23 Siegel PZ, Brackbill RM, Frazier EL, Mariolis P, Sanderson LM, Waller MN, et al. Behavioral risk factor son LM, Waller MN, et al. Behavioral risk factor
surveillance, 1986-1990. MMWR 1991; 40(SS-4): 1-23.

24 Waksberg J. Sampling methods for random digit dialing. $f$ Am Stat Assoc 1978; 73 : 40-6.

25 US Dept of Commerce. 1990 census of population and housing short form. Washington, DC: US Dept of Commerce, Bureau of the Census; 1992.

26 US Centers for Disease Control. Cigarette smoking amon adults-United States, 1991. MMWR 1993; 42: 230-3.

27 US Centers for Disease Control. Passive smoking: beliefs, attitudes, and exposures-United States, 1986. $M M W R$ $1988 ; 37: 239-41$.

28 US Department of Health and Human Services. Tobacco use in 1986: methods and basic tabulations from adult use of tobacco survey. Rockville, Maryland: US Department of tobacco survey. Rockvile, Maryland. US Department of Health and Human Services publication No $O M$ of Health

29 Brownson RC, Jackson-Thompson J, Wilkerson JC, Davis JR, Owens NW, Fisher EB. Demographic and socioeconomic differences in beliefs about the health effects of smoking. Am f Public Health 1992; 82: 99-103.

30 Brownson RC, Davis JR, Wilkerson JC, JacksonThompson J. Predictors of individual action to reduce exposure to environmental tobacco smoke. Tobacco Control 1994; 3 : 216-21.

31 Brownson RC, Jackson-Thompson J, Wilkerson JC, Kiani F. Reliability of information on chronic disease risk factors collected in the Missouri behavioral risk factor surveillance system. Epidemiology 1994; 5: 545-9.

32 Statistical Analysis System Institute Incorporated. SAS User's Guide: Basics, version 5 edition. Cary, NC: SAS Institute, 1985

33 SUDAAN User's Manual. Professional software for survey data analysis. Research Triangle Park, NC: Research Triangle Institute; 1991.

34 Snedecor GW, Cochran WG. Statistical methods, 7th ed. Ames, Iowa: The Iowa State University Press, 1980

35 Bliss $M$. No smoke. New anti-tobacco law takes effect this month. Cape Giardeau, Missouri: Southeast Missourian; August 8, 1992

36 Fulton KA. Smokers adjusting to new law. County employees making changes in workplace, style. Nevada, Missouri: Daily Mail; October 2, 1992.

37 Brothers $K$. New state law limits smoking at work, indoor public places. Joplin, Missouri: Globe; October 11, 1992.

38 New law extends breath of fresh air to Missouri. Poplar Bluff, Missouri: Daily American Republic; August 9, 1992

39 Lindecke FW. Ashcroft OKs curbs on smoking. New law targets public places, bars sales of tobacco to minors. $S t$ Louis Post-Dispatch; June 12, 1992.

40 Borland R, Pierce JP, Burns DM, Gilpin E, Johnson M, Bal D. Protection from environmental tobacco smoke in California. The case for a smoke-free workplace. $¥ A M A$ 1992; 268 : 749-52.

41 California State Law AB 13, chapter 310, 1994.

42 Maryland State Regulation .01-.05 under COMAR $09.12 .23,1994$

43 Bal DG, Kizer KW, Felten PG, Mozar HN, Niemeyer D. Reducing tobacco consumption in California: development of a statewide anti-tobacco use campaign. $\mathcal{F} A M A$ $1990 ; 264: 1570-4$

44 Breslow L, Johnson M. California's Proposition 99 on tobacco, and its impact. Annu Rev Public Health 1993; 14: 585-604.

45 Sharp DJ, Brownson RC, Sosin DM, Davis JR, Wilkerson JC, Jackson-Thompson J, et al. Exposure to environmental tobacco srioke among Missouri children. Missouri Med 1993; 90: 701-4.

46 American Academy of Pediatrics. Committee on environ- 
mental hazards. Involuntary smoking-a hazard to children. $\mathcal{F}$ Pediatr 1986; 77: 755

47 US Department of Health and Human Services. $H H S$ news. [Press release.] Washington, DC: US Department of Health and Human Services; January $7,1993$.

48 Emont SL, Choi WS, Novotny TE, Giovino GA. Clean indoor air legislation, taxation, and smoking behaviour in the United States : an ecological analysis. Tobacco Control

49 Shea S, Stein AD, Lantigua R, Basch CE. Reliability of the behavioral risk factor survey in a triethnic population. Am F Epidemiol 1991; 133: 489-500.

50 Jackson C, Jatulis DE, Fortmann SP. The behavioral risk factor survey and the Stanford five-city project survey: comparison of cardiovascular risk behavior estimates. $A m$ f Public Health 1992; 82: 412-6.

51 US Centers for Disease Control. Using chronic disease data: a handbook for public health practitioners. Atlanta, Georgia: Centers for Disease Control and Prevention, 1992

52 Fontham ETH, Correa P, Reynolds P, Wu-Williams A Buffler PA, Greenberg RS, et al. Environmental tobacco Buffer PA, Greenberg RS, et al. Environmental tobacco smoke and lung cancer in nonsmoking women. A

53 Biener L, Abrams DB, Emmons K, Follick MJ. Evaluating worksite smoking policies: methodologic issues. $N Y$ State f Med 1989; 89: 5-10.

54 Coultas DB, Samet JM, McCarthy JF, Spengler JD A personal monitoring system to assess workplace exposure to environmental tobacco smoke. Proceedings of the ASHRAE/SOEH Conference, IAQ 89. The Human Equation: Health and Comfort. San Diego, California American Society of Heating, Refrigerating, and AirConditioning Engineers, April 17-20, 1989.

55 Siegfried J. Largest tobacco-control program begins. $7 \mathrm{Nat}$ Cancer Inst 1991; 83: 1446-7.

56 Missouri ASSIST Project. Annual Action Plan-1993. Columbia, MO: Missouri Department of Health, Division of Chronic Disease Prevention and Health Promotion, 1993.

57 Samuels B, Glantz SA. The politics of local tobacco control. fAMA 1991; 266: 2110-7.

58 Jackson-Thompson J, Hagan R, Wilkerson J Davis JR Brownson RC, Fisher EB. From basic BRFSS to special surveys: the collection, analysis and use of state, to special local data. In: Proceedings of the 1991 Public Health local data. In: Proceedings of the 1991 Public Health Conference on Records and Statistics. Hyattsville, Maryland: US Department of Health and Human Services, National Center for Health Statistics, 1991. (DHHS Publication No (PHS) 92-1214: 337-42.

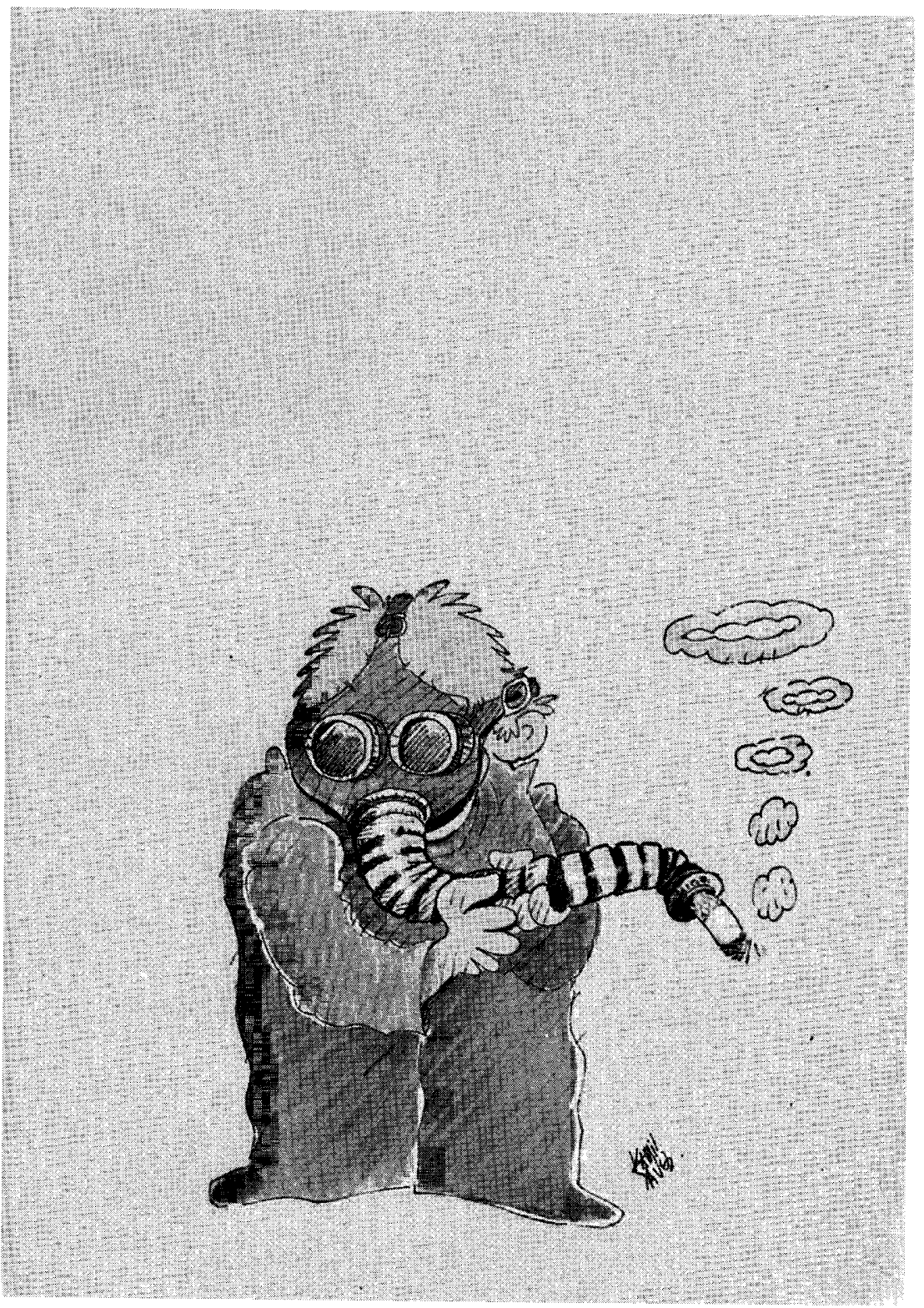

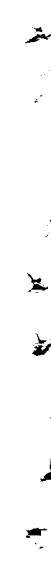

$\therefore$

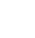

